\title{
ESTÍMULO DO COMPORTAMENTO FOTOAUTOTRÓFICO DURANTE O ENRAIZAMENTO IN VITRO DE Annona glabra L., I. DESENVOLVIMENTO DO SISTEMA RADICULAR E DA PARTE AÉREA
}

\author{
Stimulus of the photoautotrophic behavior during the in vitro rooting of Annona glabra L., I. \\ Development of root system and shoot
}

\author{
José Raniere Ferreira de Santana ${ }^{1}$, Renato Paiva ${ }^{2}$, Flávia Dionísio Pereira ${ }^{1}$, Lenaldo Moniz de Oliveira ${ }^{1}$
}

\begin{abstract}
RESUMO
Conduziu-se este trabalho, com o objetivo de induzir a estímulo do comportamento fotoautotrófico durante o enraizamento in vitro em brotações de Annona glabra L. Brotações oriundas de cultivo em tubos fechados com tampa e película de PVC (cultivo sem aeração), com tampa sem a película de PVC e tampão de algodão (cultivo com aeração) foram inoculadas em meio WPM suplementado com 4,9 $\mu \mathrm{M}$ de AIB e 164,4mM de carvão ativado na presença $(58,42 \mathrm{mM})$ ou ausência de sacarose. Durante o enraizamento, foram mantidas as mesmas condições de vedação dos tubos de ensaio em que as brotações foram induzidas. Após a inoculação, os tubos contendo os explantes foram mantidos em sala de crescimento sob radiação fotossintética ativa de 45-56 $\mu$ mol.m${ }^{2} \cdot \mathrm{s}^{-1}$ a $25 \pm 3^{\circ} \mathrm{C}$. Os resultados mostraram que o enraizamento das brotações de A. glabra não dependeu do suprimento de sacarose no meio de cultura, em tubos fechados com o tampão de algodão ou tampa plástica sem PVC. A aeração dos tubos de ensaio trouxe incrementos de significativos (até 250\%) na matéria seca radicular. A indução de raízes secundárias (laterais) em A. glabra só ocorreu em culturas com aeração, independentemente da presença ou ausência de sacarose no meio de cultura. Com os resultado desse experimento, conclui-se que o estímulo do comportamento fotoautotrófico em A.glabra pode ser obtido com sucesso durante a fase de enraizamento in vitro.
\end{abstract}

Termos para indexação: Aeração in vitro, cultura de tecidos, redução de custos, fotoautotrofia, Annona glabra.

\section{ABSTRACT}

The objective of the present work was to evaluate whether Annona glabra $\mathrm{L}$. shoots are able to acquire the photoautotrophic behavior during the in vitro rooting. In vitro A. glabra shoots originated from cultures in vessels sealed with cap and PVC film (culture without aeration), cap without PVC film or cotton tampon (cultures with aeration), were inoculated in WPM medium supplemented with $4.9 \mu \mathrm{M}$ IBA and $164,4 \mathrm{mM}$ activated charcoal in the presence $(58.42 \mathrm{mM})$ or absence of sucrose. During rooting, the same conditions in which shoots were induced were maintained. After inoculation, the tubes with explants were maintained in growth room under photosynthetic active radiation of $45-56 \mu \mathrm{mol} \cdot \mathrm{m}^{-2} \cdot \mathrm{s}^{-1}$ and of temperature $25 \pm 3^{\circ} \mathrm{C}$. The results showed that the rooting of $A$. glabra shoots do not depend on the supply of sucrose into culture medium, in vessel with aeration. Aeration of cultures brought expressive increments of dry weight of roots (up to 250\%). The induction of secondary (side) roots was found only in cultures with aeration, independently of sucrose presence. One concluded that the acquisition of the photoautotrophic behavior in A. glabra may be obtained with success during the in vitro rooting phase.

Index terms: In vitro hardening, tissue culture, cost reduction, photoautotrophy, Annona glabra.

(Recebido em 2 de fevereiro de 2007 e aprovado em 9 de julho de 2007)

\section{INTRODUÇÃO}

A espécie Annona glabra L. se destaca por produzir frutos apreciados tanto para a fauna nativa como para a alimentação humana. Devido à intensa exploração predatória da cultura, justifica a elaboração de cultivos alternativos e neste sentido, a micropropagação surge como uma escolha promissora. Porém, para que as mudas micropropagadas se tornem viáveis comercialmente e competitivas com o mercado tradicional de propagação, é necessário reduzir os custos de produção devidos em grande parte às perdas ocorridas em virtude do processo que se desenvolvem (ERIG \& SCHUCH, 2005; INOUE et al., 1998).

A micropropagação fotoautotrófica (sem açúcar) apresenta várias vantagens sob o método heterotrófico (com açúcar) tais como o aumento do crescimento das plantas, redução do risco de contaminação microbiana, melhoria das características fisiológicas da planta, redução do estresse da planta durante a aclimatização, eliminação

${ }^{1}$ Doutores - Departamento de Biologia/DBIO - Laboratório de Cultura de Tecidos - Unidade Experimental Horto Florestal - Universidade Estadual de Feira de Santana/UEFS - Avenida Presidente Dutra, s/n - Santa Mônica - 44055-000 - Feira de Santana, BA - raniere@uefs.br; flavia1808@hotmail.com; lenaldo@ufes.br

${ }^{2}$ Ph. D., Professor - Departamento de Biologia/DBI - Universidade Federal de Lavras/UFLA - Cx. P. 3037 - 37200-000-Lavras, MG - renpaiva@ufla.br 
dos custos com iluminação, reparos, manutenção e ainda, possibilita utilizar instalações simplificadas diminuindo os custos das construções (ERIG \& SCHUCH, 2005). Segundo Zobayed et al. (2002), outra grande vantagem da micropropagação fotoautotrófica é a possibilidade de usar grandes recipientes de cultura com o risco mínimo de contaminação.

A fotoautotrofia é restringida principalmente pela baixa concentração de $\mathrm{CO}_{2}$ nos frascos de cultivo durante o fotoperíodo e também pela presença de açúcar no meio de cultura (HDIDER \& DESJARDINS, 1994; KOZAI, 1991a). Várias pesquisas revelam que ela pode ser estimulada através da redução de carboidrato no meio, aumentando a intensidade luminosa e elevando a concentração de $\mathrm{CO}_{2}$ (CALVETE et al., 2002; GEORGE, 1996; KOZAI, 1991b). Langford \& Wainwright (1987) sugerem que as alterações anatômicas e fisiológicas que podem vir a surgir nos explantes cultivados sob regime heterotrófico não possibilitam que o aparato fotossintético opere normalmente, porque a utilização do dióxido de carbono é reprimida pela presença de sacarose exógena. Grout \& Donkin (1987) complementam afirmando que esta repressão ocorre devido à inibição da enzima ribulose bisfosfato carboxilase, a qual, segundo George (1993), permanece após a transferência para um meio de cultura livre de sacarose.

Verifica-se que quando ocorre o aumento do $\mathrm{CO}_{2}$ simultaneamente, há redução da umidade relativa e da concentração de etileno em torno da planta e para tanto, têm-se utilizado alguns métodos, tais como perfurar a tampa e preencher o orifício com tampões, fazer aberturas laterais nos recipientes de cultura ou tampar os frascos com um filtro, que podem ser usados para aumentar as trocas gasosas (KOZAI \& NGUYEN, 2003; MURPHY et al., 1998).

A melhora nas trocas gasosas entre a atmosfera interna do frasco de cultura e o meio externo conduz a um efeito positivo sobre o crescimento e sobre a estímulo do comportamento fotoautotrófico. E é por isso que em alguns casos é possível crescer plantas in vitro mais rapidamente sob condições fotoautotróficas do que sob condições hetero ou mixotróficas, desde que o ambiente físico no interior dos frascos seja controlado adequadamente para a promoção do processo fotossintético (GROUT, 1988). Neste contexto Serret et al. (1997), avaliaram o crescimento de plantas de Gardenia jasminoides Ellis e o desenvolvimento da fotoautotrofia durante os estádios de multiplicação e enraizamento in vitro. Os autores concluíram que a fotoautrotofia é mais fácil de ser induzida na fase de enraizamento e a baixa concentração de sacarose induziu o mais alto grau de fotoautrotofia, sendo que o efeito mais evidente foi verificado em plantas cultivadas em tubos pouco retidos na vedação.

Sendo assim, objetivou-se com este trabalho, induzir o estímulo do comportamento fotoautotrófico durante o enraizamento in vitro em brotações de Annona glabra reduzindo a concentração de sacarose e utilizando vedações alternativas.

\section{MATERIAL E MÉTODOS}

Como fonte de explantes, foram utilizadas brotações preestabelecidas in vitro mantidas em tubos de ensaio (25x150mm) vedados de três maneiras: tampa envolvida com película de PVC, tampa sem película de PVC e tampão de algodão. As brotações tinham o comprimento médio de 31,$00 ; 23,00$ e 22,75mm, respectivamente, e todas tinham pelo menos um par de folhas expandidas.

Os explantes foram inoculados em dois meios de enraizamento: 1) meio WPM solidificado com $7 \mathrm{~g} . \mathrm{L}^{-1}$ de ágar e suplementado com 4,9 $\mu$ M AIB, 164,4mM carvão ativado sem sacarose; 2) meio igual ao anterior acrescido de $58,42 \mathrm{mM}$ sacarose (Testemunha). $\mathrm{O} \mathrm{pH}$ do meio de cultura foi ajustado para 5,7 antes da autoclavagem.

Foram avaliadas três tipos de vedações dos tubos: tampa plástica envolvida ou não com a película de PVC e o tampão de algodão. Utilizou-se $10 \mathrm{~mL}$ de meio de cultura nos tubos de ensaio com tampa envolvida com película de PVC e 20mL nos tubos vedados com tampa sem a película de PVC e com o tampão de algodão. Após a inoculação, as culturas foram mantidas em sala de crescimento com temperatura de $25 \pm 3^{\circ} \mathrm{C}$, fotoperíodo de 16 horas com radiação fotossintética ativa de $45-56 \mu \mathrm{mol} \mathrm{m}^{-2} \mathrm{~s}^{-1}$, durante 60 dias.

Avaliaram-se as seguintes variáveis: porcentagem de enraizamento, número de raízes adventícias, número de raízes secundárias (laterais), comprimento maior raiz ( $\mathrm{mm})$, matéria seca da parte aérea, da raiz e a total $(\mathrm{mg})$.

$\mathrm{O}$ delineamento experimental utilizado foi o inteiramente casualizado em arranjo fatorial $2 \times 3$ (concentrações de sacarose $\mathrm{x}$ tipos de vedação) com 5 repetições, sendo cada uma formada por três tubos.

Os dados foram avaliados estatisticamente, mediante a análise de variância usando arranjo fatorial, testando-se as médias pelo teste de Tukey. Os dados de percentagens foram transformados em arco-seno $\sqrt{\%} \mathrm{e}$ os número de contagem, em $\sqrt{x+1}$. O programa utilizado para análise dos dados foi o software SISVAR (FERREIRA, 2003). 


\section{RESULTADOS E DISCUSSÃO}

Todas as brotações transferidas para o meio de enraizamento a que foram submetidas, enraizaram. As raízes eram bem formadas e não apresentavam formação de calos.

O enraizamento das brotações não foi dependente do suprimento de carbono no meio de cultura. Entretanto, foi altamente influenciado pelo tipo de vedação dos tubos. Os maiores percentuais de enraizamento foram encontrados nos tubos vedados com tampa sem a película de PVC e com o tampão de algodão. As maiores porcentagens de enraizamento foram de $85 \%$ para os tubos vedados com tampa sem a película de PVC e 75\% nos tubos vedados com tampão de algodão. Com o método tradicional de vedação dos tubos obteve-se $40 \%$ de enraizamento (Figura 1A).
Na comparação entre os meios com e sem suplementação de sacarose, observou-se que apesar do maior número de raízes adventícias ter sido encontrado no meio com sacarose (1,61 por microplanta), o ganho foi de apenas 36,4\% (Figura 1B). Quando comparados os três métodos de vedação, os maiores números de raízes adventícias foram obtidos em brotações cultivadas em tubos fechados com tampa sem PVC (1,82 por brotação) e tampão de algodão (1,75 por brotação), que diferiram significativamente do valor obtido com o método tradicional de vedação dos tubos $(0,62$ por brotações $)$. A retirada da película de PVC da tampa contribuiu com aumento de 193,5\% no número de raízes adventícias. Entre as vedações com tampão de algodão e tampa sem PVC, não houve diferenças significativas (Figura 1C).
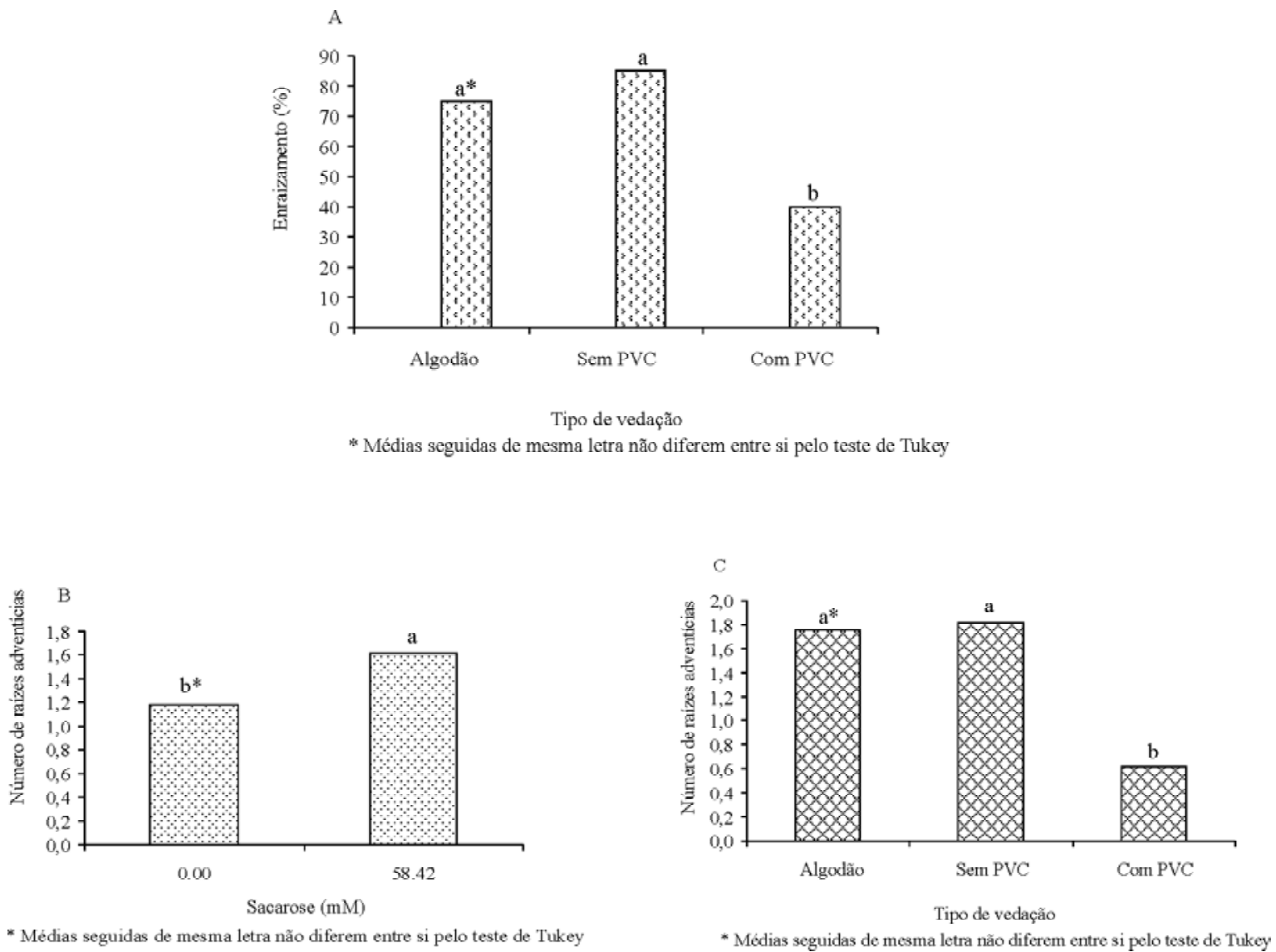

Figura 1 - Enraizamento de Annona glabra em função da presença ou ausência de sacarose e do tipo de vedação (A) porcentagem de enraizamento (B) número de raízes adventícias em função da sacarose e $(C)$ número de raízes adventícias em função da vedação. Lavras, MG, 2006. 
Em tubos completamente vedados não houve emissão de raízes secundárias (laterais). $\mathrm{O}$ maior número foi de 4,25 por microplanta quando os tubos foram vedados com o tampão de algodão, em meio sem sacarose. O ganho nas trocas gasosas, advindo do tampão de algodão, estimulou a emissão de raízes secundárias para suprir a maior demanda transpiratória. Por outro lado, em tubos fechados com o tampão de algodão, a adição de $58,42 \mathrm{mM}$ de sacarose ao meio de cultura causou uma redução de 304\% no número de raízes secundárias (Tabela 1).

Quanto ao comprimento da maior raiz, matéria seca da parte aérea e das raízes e matéria seca total, a interação concentração de sacarose $\mathrm{x}$ tipo de vedação foi significativa para as variáveis matéria seca da parte aérea e matéria seca total das plantas. Os efeitos isolados de sacarose e do tipo de vedação foram altamente significativos para as variáveis comprimento da maior raiz e matéria seca das raízes.

A presença de sacarose no meio de cultura estimulou o crescimento das raízes adventícias, entretanto, o tipo de vedação foi o fator que mais influenciou no crescimento das raízes. No meio com sacarose as raízes cresceram $30,35 \mathrm{~mm}$ enquanto que no meio sem sacarose o crescimento foi de $18,15 \mathrm{~mm}$ (Figura 2A). Quando os tubos foram completamente vedados com tampa e PVC, as raízes apresentaram o menor comprimento médio $9,02 \mathrm{~mm}$, e com o tampão de algodão ou tampa sem PVC, o comprimento médio da maior raiz foi de 31,75 e $31,95 \mathrm{~mm}$ representando um acréscimo de $250 \%$ no crescimento radicular (Figura 2B).

Em meio de cultura suplementado com sacarose, obteve-se maior matéria seca de raiz 1,98. No meio sem sacarose obteve-se 1,04 (Figura 2C). Como nas demais variáveis, a maior contribuição para a matéria de raiz veio do fator tipo de vedação. As raízes produzidas em tubos com o tampão de algodão apresentaram o maior peso médio $(2,17 \mathrm{mg} /$ planta), seguido pela vedação com tampa sem PVC $(1,74 \mathrm{mg} /$ planta). O menor peso médio foi de $0,62 \mathrm{mg} /$ planta em frascos vedados com tampa e PVC. Esses dois tipos de vedações superaram significativamente a vedação com tampa com PVC (Figura 2D). Em termos percentuais, o ganho de matéria radicular foi de 250 e $180 \%$ quando se utilizou o tampão de algodão ou a tampa sem PVC para fechar os tubos.
Com a vedação total dos tubos, o acúmulo de matéria seca na parte aérea não respondeu à presença de sacarose no meio de cultura. Entretanto, com a remoção da película de PVC da tampa, em meio sem sacarose subiu de 7,04mg para $13,18 \mathrm{mg} /$ brotação, e em meio com sacarose de 7,38 para $18,40 \mathrm{mg} /$ brotação. Em termos percentuais, esses valores representam, respectivamente, ganhos de $87,2 \%$ e $149,3 \%$. Quando os tubos foram fechados com o tampão de algodão, não houve limitação alguma para as trocas gasosas e a fotossíntese ocorreu normalmente, o que resultou em um grande acúmulo de matéria $25,82 \mathrm{mg}$ /brotação que, comparado com o método mais comum de enraizamento em meio com sacarose em tubos completamente vedados, representa um ganho de $250 \%$ na matéria seca (Tabela 2).

Em média, quando os tubos foram vedados com tampa e PVC, a matéria seca total das plantas não aumentou de maneira significativa com a adição de sacarose ao meio de cultura. Em tubos vedados com o tampão de algodão, a matéria seca total foi maior em meios sem sacarose $(27,65 \mathrm{mg} /$ brotação), enquanto que em tubos com tampa sem PVC, a resposta à sacarose foi positiva $(20,91 \mathrm{mg} /$ brotação) (Tabela 2).

$\mathrm{O}$ tipo de vedação dos frascos foi o fator que mais influenciou as variáveis estudadas. A vedação dos frascos com tampa plástica sem PVC e com o tampão de algodão foram adequadas por prevenir o ressecamento, a contaminação e permitir as trocas gasosas com o ambiente externo, proporcionando um enraizamento satisfatório. Resultados semelhantes foram observados por Cruzzuol et al. (1995), os autores verificaram que a vedação com tampão de algodão em cravo (Dianthus caryophyllus L.) propagados in vitro foi mais eficiente quando comparada com a vedação feita com papel alumínio. Já Souza et al. (1999), verificando a influencia dos fatores físicos na regeneração de brotos de repolho (Brassica oleracea L.), observaram que quando se apertava a rosca das tampas nos frascos, ocorriam superbrotamento e estiolamento dos brotos, em virtude do acúmulo de compostos voláteis, no interior dos frascos. Neste mesmo sentido, Marino et al. (1995) também observaram um acúmulo de gases $\left(\mathrm{CO}_{2}\right.$ e etileno) quando utilizaram diferentes tampas plásticas e de alumínio.

Tabela 1 - Número de raízes secundárias (laterais) de plantas de Annona glabra, em função de presença ou ausência de sacarose e de diferentes tipos de vedações dos tubos de ensaio. Lavras - MG, 2006.

\begin{tabular}{ccccc}
\hline Sacarose $(\mathrm{mM})$ & \multicolumn{3}{c}{ Tipo de vedação } & Média \\
\cline { 2 - 4 } & Tampão de algodão & Tampa sem PVC & Tampa com PVC & $1,62 \mathrm{a}$ \\
\hline 0,00 & $4,25 \mathrm{~A}^{\mathrm{z}} \mathrm{a}^{\mathrm{y}}$ & $0,60 \mathrm{~B} \mathrm{~b}$ & $0,00 \mathrm{~B} \mathrm{a}$ & $0,90 \mathrm{~b}$ \\
\hline Média & $1,05 \mathrm{~A} \mathrm{~b}$ & $1,62 \mathrm{~A} \mathrm{a}$ & $0,00 \mathrm{~B} \mathrm{a}$ & $0,00 \mathrm{C}$ \\
\hline
\end{tabular}

\footnotetext{
z - Médias seguidas pela mesma letra maiúscula, em cada linha, não diferem entre si ao nível de $5 \%$ de probabilidade pelo teste de Tukey.
}

y - Médias seguidas pela mesma letra minúscula, em cada coluna, não diferem entre si ao nível de $5 \%$ de probabilidade pelo teste de Tukey. 

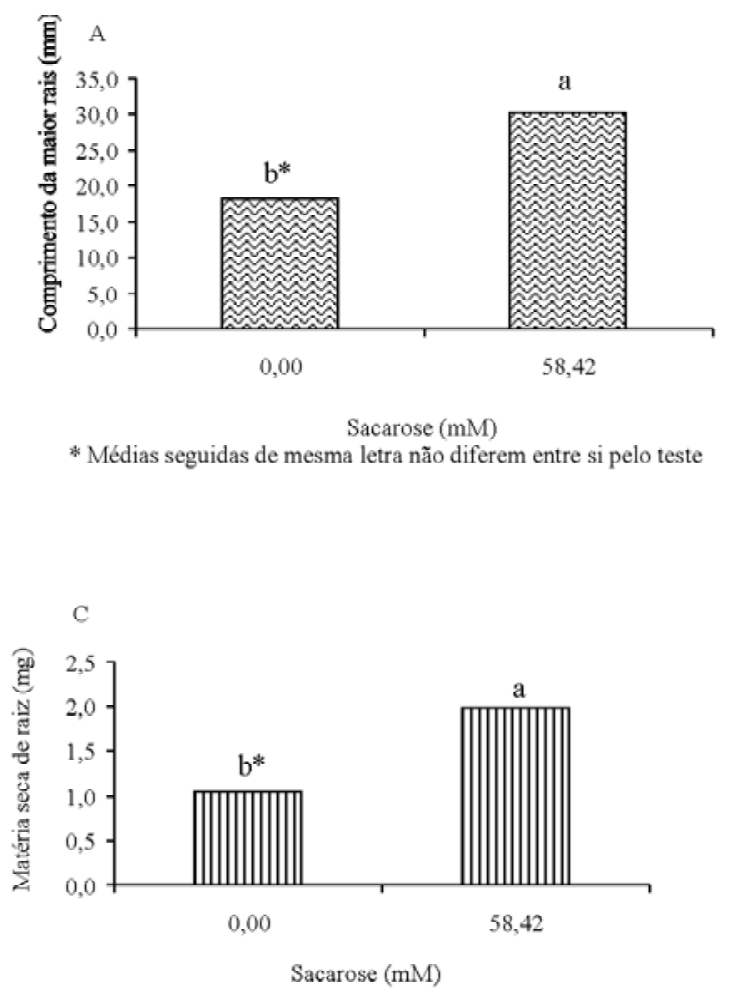

* Médias seguidas de mesma letra não diferem entre si pelo teste de Tukey

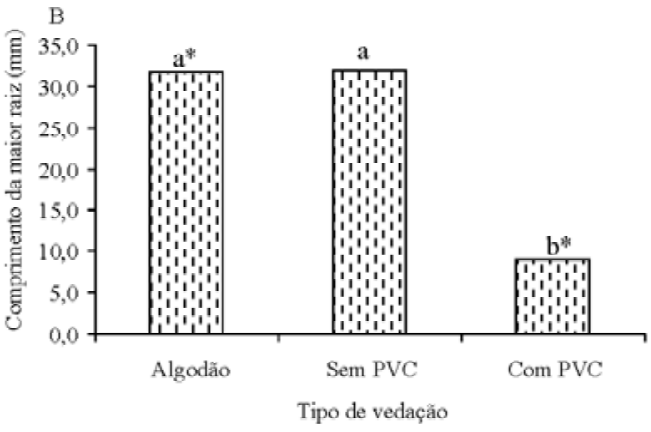

* Médias seguidas de mesma letra não diferem entre si pelo teste de Tukey

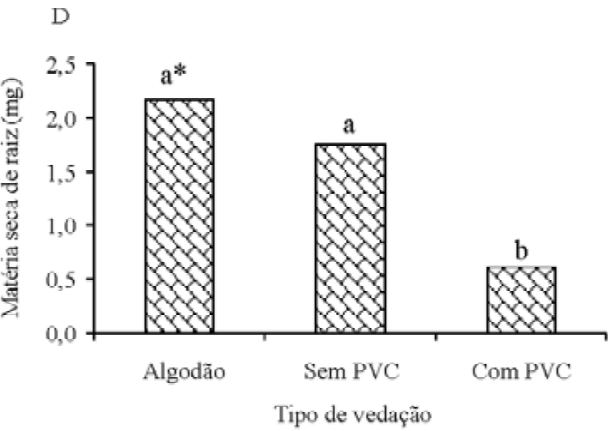

* Médias seguidas de mesma letra não diferem entre si pelo teste de Tukey

Figura 2 - Enraizamento de Annona glabra em função da presença ou ausência de sacarose e do tipo de vedação (A) comprimento da maior raiz em função da sacarose (B) comprimento da maior raiz em função da vedação (C) matéria seca de raiz em função da sacarose (D) matéria seca de raiz em função da vedação. Lavras, MG, 2006.

Tabela 2 - Matéria seca da parte aérea e total (mg) de plantas de Annona glabra, em função de presença ou ausência de sacarose e de diferentes tipos de vedações dos tubos de ensaio. Lavras - MG, 2006.

\begin{tabular}{|c|c|c|c|c|}
\hline \multicolumn{5}{|c|}{ Matéria Seca da Parte Aérea } \\
\hline \multirow[t]{2}{*}{ Sacarose $(\mathrm{mM})$} & \multicolumn{3}{|c|}{ Tipo de vedação } & \multirow[b]{2}{*}{ Média } \\
\hline & Tampão de algodão & Tampa sem PVC & Tampa com PVC & \\
\hline 0,00 & $25,82 \mathrm{~A}^{\mathrm{z}} \mathrm{a}^{\mathrm{y}}$ & $13,18 \mathrm{~A} \mathrm{a}$ & $7,04 \mathrm{~B}$ a & $15,35 \mathrm{a}$ \\
\hline 58,42 & $19,95 \mathrm{~A} \mathrm{~b}$ & $18,40 \mathrm{~A} \mathrm{a}$ & $7,38 \mathrm{~B}$ a & $15,24 \mathrm{a}$ \\
\hline Média & $22,88 \mathrm{~A}$ & $15,79 \mathrm{~B}$ & $7,21 \mathrm{C}$ & \\
\hline \multicolumn{5}{|c|}{ Matéria Seca Total } \\
\hline 0,00 & $27,65 \mathrm{~A} \mathrm{a}$ & $14,19 \mathrm{~B} \mathrm{~b}$ & $7,36 \mathrm{C} \mathrm{a}$ & $16,40 \mathrm{a}$ \\
\hline 58,42 & $22,08 \mathrm{~A} \mathrm{~b}$ & $20,91 \mathrm{~A} \mathrm{a}$ & $8,30 \mathrm{~B}$ a & $17,10 \mathrm{a}$ \\
\hline Média & $24,86 \mathrm{~A}$ & $17,55 \mathrm{~B}$ & $7,84 \mathrm{C}$ & \\
\hline
\end{tabular}

Ciênc. agrotec., Lavras, v. 32, n. 1, p. 80-86, jan./fev., 2008 
Embora vários autores mencionem como sendo indispensável o fornecimento de sacarose no processo de enraizamento in vitro (BOSA et al., 2003; CALVETE et al., 2002; LEITE et al., 2000; SEON et al., 1999) a presença de sacarose no meio foi dispensável na fase de enraizamento de Annona glabra, confirmando a afirmação de Grout (1988) quando relata a possibilidade de plantas se adaptar as condições fotoautotróficas in vitro, apesar das condições artificiais de cultivo, podendo até ter uma significante taxa fotossintética.

Em termos de qualidade, houve uma tendência em produzir um sistema radicular mais completo e funcional, com formação inclusive de raízes secundárias e sem a formação de calos o que dificultaria a conexão do sistema vascular entre o caule e raiz. Esses resultados estão de acordo com Rasai et al. (1995) os quais reportaram evidencias da fotoautotrofia em explantes de atemóia (Annona squamosa L. x Annona cherimola L.) reduzido sacarose para $0,75 \%$. Resultados similares foram também encontrados em plantas de rosa (Rosa sp.), a fotossíntese aumentou quando a concentração de sacarose no meio de crescimento foi reduzida (LANGFORD \& WAINWRIGHT, 1987).

Portanto, a técnica de enraizamento fotoautotrófico descrito nesse trabalho pode contribuir para a propagação em larga escala de Annona spp. A aeração natural provou ser uma alternativa viável, mais interessante que o uso de antagonistas de etileno ou mesmo a ventilação forçada dos recipientes de cultura. Combinado com o meio livre de sacarose, a aeração natural, estimulou a mudança do modo de crescimento heterotrófico para fotoautotrófico durante a fase de enraizamento, o que facilitou e diminuiu o período de aclimatização.

\section{CONCLUSÕES}

O enraizamento das brotações de Annona glabra, originárias de cultivo in vitro, não depende do suprimento de carbono no meio de cultura, em tubos fechados com o tampão de algodão ou tampa plástica sem PVC.

A aeração dos tubos de ensaio traz incrementos significativos (até $250 \%$ ) na matéria seca radicular. A indução de raízes secundárias (laterais) em Annona glabra só ocorre em culturas com aeração.

O estímulo do comportamento fotoautotrófico é obtido com sucesso durante a fase de enraizamento in vitro.

\section{REFERÊNCIAS BIBLIOGRÁFICAS}

BOSA, N.; CALVETE, E. O.; SUZIN, M.; BORDIGNON, L. Avaliação do crescimento de Gypsophila paniculata durante o enraizamento in vitro. Horticultura Brasileira, Brasília, v. 21, n. 3, p. 510-513, jul./set. 2003.
CALVETE, E. O.; KÄMPF, A. N.; SUZIN, M. Concentração de sacarose no enraizamento in vitro de morangueiro. Horticultura brasileira, Brasília, v. 20, n. 2, p. 186-191, jun. 2002.

CUZZUOL, G. R. F.; GALlO, L. A.; ALMEIDA, M. de; CROCOMO, O. J. Controle da vitrificação do cravo (Dianthus caryophyllus L.). Sciencia agrícula, Piracicaba, v. 52, n. 3, p. 604-614, set./dez. 1995.

ERIG, A. C.; SCHUCH, M. W. Micropropagação fotoautotrófica e uso da luz natural. Ciência Rural, Santa Maria, v. 35, n. 4, p. 961-965, jul./ago. 2005.

FERREIRA, D. F. SISVAR. Versão 4.3. Lavras: UFLA, 2003.

GEORGE, E. F. Plant propagation by tissue culture: the technology. 2. ed. Edington: Exegetics, 1993. part 1, 574 p.

GEORGE, E. F. Plant propagation by tissue culture. 2. ed. Edington: Exegetics, 1996. part 2, 1361 p.

GROUT, B. W. W. Photosynthesis of regenerated plantlets in vitro, and stress of transplanting. Acta Horticulturae, Wageningen, n. 230, p. 129-135, 1988.

GROUT, B. W. W.; DONKIN, M. E. Photosynthetic activity of cauliflower meristem cultures in vitro and at transplanting into soil. Acta Horticulturae, Wageningen, v. 212 , p. $323-327,1987$.

HDIDER, C.; DESJARDINS, Y. Effects of sucrose on photosynthesis and phosphoenolpyruvate carboxylase activity of in vitro culture strawberry plantlets. Plant Cell, Tissue and Organ Culture, Dordrechet, v. 36, n. 1, p. 27 33, Jan. 1994.

INOUE, M. T.; GRAÇA, M. E. C.; CORREA, G. Capacidade fotossintética de plântulas micropropagadas e de mudas de Eucalyptus tereticornis sm. Boletim de Pesquisa Florestal, Colombo, n. 36, p. 71-77, jan./jun. 1998.

KOZAI, T. Micropropagation under photoautotrophic conditions. In: DEBERGH, P.; ZIMMERMAN, R. (Eds.). Micropropagation, technology and application. Dordrecht: Kluwer Academic, 1991a. p. 447-469.

KOZAI, T. Photoautotrophic micropropagation. In Vitro Cellular and Developmental Biology - Plant, Columbia, v. 27, n. 1, p. 47-51, Jan./Feb. 1991b. 
KOZAI, T.; NGUYEN, Q. T. Photoautotrophic micropropagation of woody and tropical plants. In: JAIN, S. M.; ISHII, K. Micropropagation of woody trees and fruits. Dordrecht: Kluwer Academic, 2003. p. 757-781.

LANGFORD, P. J.; WAINRIGHT, S. Effects of sucrose concentration on the photosynthesis ability of rose shoots in vitro. Annals of Botany, London, v. 60, n. 5, p. 633-640, May 1987.

LEITE, G. B.; FINARDI, N.; FORTES, G. R. L. Efeito de concentrações de sacarose no meio de cultura e da intensidade luminosa no enraizamento in vitro do portaenxerto de Pereira OH x F97. Ciência e Agrotecnologia, Lavras, v. 24, n. 2, p. 335-357, abr./jun. 2000.

MARINO, G.; BERARDI, G.; ANCHERANI, M. The effect of the type of closure on the gas composition of the headspace and the growth of GF 677 peach $x$ almond rootstack cell suspension culture. In Vitro Cellular Development Biology Plant, Columbia, v. 31, n. 4, p. 207 210, 1995.

MURPHY, K. P.; SANTAMARIA, J. M.; DAVIES, W. J.; LUMSDEN, P. J. Ventilation of culture vassels: I. increased growth in vitro and survival ex vitro of Delphinium. The Journal of Horticultural Science \& Biotechnology, Ashford, v. 73, n. 5, p. 725-729, Sept. 1998.
RASAI, S.; GEORGE, A. P.; KANTHARAJAH, S. Tissue culture of Annona spp. (cherimoya, atemoya, sugar apple and soursop): a review. Scientia Horticulturae, Amsterdam, v. 62, n. 1/2, p. 1-14, Apr. 1995.

SEON, J. H.; CUI, C. H.; PAEK, K. Y.; YANG, C. S.; GAO, W. Y.; PARK, C. H.; SUNG, S. N. Effects of air exchange, sucrose, and PPF on growth of Rehmannia glutinosa under enriched $\mathrm{CO} 2$ concentration in vitro. Acta Horticulture, Amsterdam, v. 502, p. 313-318, 1999.

SERRET, M. D.; TRILLAS, M. I.; MATAS, J.; ARAUS, J. L. The effect of different closure types, light and sucrose concentration on carbon isotope composition and growth of Gardenia jasminoides plantlets during micropropagation and subsequent acclimation ex vitro. Plant Cell, Tissue and Organ Culture, Dordrechet, v. 47, n. 3, p. 217-230, 1997.

SOUZA, C. M.; PINTO, J. E. B. P.; RODRIGUES, B. M.; MORAIS, A. R.; ARRIGONI-BLANK, M. F. Influência dos fatores físicos na regeneração de brotos em repolho. Ciência e Agrotecnologia, Lavras, v. 23, n. 4, p. 830-835, out./dez. 1999.

ZOBAYED, S. M. A.; ARMSTRONG, J.; ARMSTRONG, W. Multiple shoot induction and leaf and flower bud abscission of Annona cultures as affected by types of ventilation. Plant Cell, Tissue and Organ Culture, Dordrechet, v. 69, n. 2, p. 155-165, May 2002. 